\title{
ASSESSMENT OF MICROBIOLOGICAL INDICATORS IN VLORA BAY, ALBANIA
}

\author{
Aurora Bakaj ${ }^{1}$, Hajdar Kiçaj ${ }^{2}$ Ambra Ferati $^{3}$ \\ 1,2,3 Biology Department, Faculty of Technical Sciences, University “Ismail Qemali” Vlore, Albania
}

\begin{abstract}
-
Vlora bay represents one of the most attractive and important beaches of Albanian seacoast. Coastal waters are widely used for a series of recreative activities. Therefore, it is needed a periodical assessment of water quality in order to improve public health. The aim of this research study was monitored and evaluation of water quality in correlation of the dynamics of fecal bacteria indicators in Vlora bay. Setting and design: The microbiological indicator analyses were conducted in 2019 at regular time intervals during two seasons: spring and summer. Water samples were collected at 6 sampling stations eventually distributed along the coastline. Materials and Methods: Total and fecal coliform were analyzed using one of the Coliform standard methods -MPN. In order to give a completed pattern of the study area, we measured some of the physical-chemical parameters such as: temperature, $\mathrm{pH}$ and salinity. The results: Temperature values vary from $11.6^{\circ} \mathrm{C}$ in March to $23.7^{\circ} \mathrm{C}$ in August. During summer time, our data show a higher concentration level of fecal bacteria almost in all the sampling stations. This might be due overpopulation of the coastline, especially in this period of year. Conclusions: This study shows that the sea water along Vlora coastline is largely indicated by anthropogenic sources. A lower quality of water is noticed particularly around the locations of urban sewage discharges.
\end{abstract}

Keywords: Fecal coliforms, monitoring; microbial indicators, water quality, MPN method

\section{Introduction}

Vlora bay is situated in the South-West of Albania. It is a closed bay with a limited water transition with Adriatic sea waters through the entrance canal. The bay area is confined in the north-west of Narta lagoon, urban area in eastern and Orikumi lagoon in the south. The typical construction of this bay creates a natural barrier protecting from winds, leaving it open only in north-west side (Alm EW, 2003). Seawater is a natural environment richer in flora and fauna as well as microorganisms such as bacteria and protozoa. Most part of these organisms do not affect human health, but a small part of pathogenic bacteria might be present in different period of time (Strickland\&Parsons, 1972).

Coastal waters are affected by anthropogenic pollution, such as sewage discharges, agricultural and industrial flows, birds, animals, river discharges, etc., having a large 


\section{2-24 November, $2019 \quad$ Paris, France}

impact on the microbiological content of seawaters (Kamizoulis\&Saliba, 2004; Kennish 1997; Wilkes et al., 2009).

The microbiological content would affect on the environment amount and quality, since it is well known that human during their different activities might be in contact with superficial or depth waters.

The potential health risk of infective diseases caused by water can be measured through the detection of universal microbiological indicators. All the regulations for determining public health are mainly based on the number or even in the presence (absence) of important microbiological pathogen indicators. The indicators of the fecal contamination levels include: Total coliform (TC), Fecal coliform (FC) and Fecal streptococci (FS) (Camper et al., 1996; CEC 1978; ISO 1991).

Fecal coliform bacteria are microscopic organisms which live in the intestinal system of a worm-blood organisms. They also live in waste materials on these, excreted from the intestinal tract. In case of a large number of these bacteria in water samples, means that water had a large fecal amount from a variety of sources. Although coliform bacteria are not direct indicators of illness, they can indicate the presence of disease carrying organisms which lives in the same environment with fecal coliform bacteria (APHA 1992; ISO 1986). Thermtolerant coliform bacteria are subunit of total coliform bacteria that has a closed and direct relationship with homothermic fecal pollution (Geldreich, 1967).

These coliform bacteria own all the features as total coliform bacteria (aerobe, facultative anaerobe, Gram- negative, non spore forming, rod-shaped, ferment lactose with gas production and acid within 24 to 48 hours in $36 \pm 1{ }^{\circ} \mathrm{C}$ ), but also grow and ferment lactose by producing gas and acid on $44.5 \pm 0.2^{\circ} \mathrm{C}$ in 48 hours of incubation. For these reasons the term: thermotolerant coliform is more adaptable for these kind of set (WHO, 1993).

Fecal contamination affects not only water quality but also is a potential risk for human health (Fleisher et al., 1998; Kay et al., 1994). After the contact with polluted sea water (a low microbiology quality), regarding the clinical point of view is reported diarrhea, nausea, and in extreme cases this might lead to death (Salyers\&Whitt 2012). Therefore the measurements conservation of seawater qualities is an important issue of public health. The correlation between water microorganisms and diseases caused by them are evidenced several times and have been reported (MREW 2000). In spite this, because of a series of complexity of this correlation between diseases and the microbiological quality of water is difficult to be defined.

Recently the urbanization and human activity in the Vlora bay is increasing with higher intensity than before. Regarding this our work is focused on studying coastal 


\section{2-24 November, $2019 \quad$ Paris, France}

waters of urban area, fulfilled with non-treated water discharges. The assessment of water quality is performed by measurement of some physical-chemical parameters and the concentration levels of microorganism as pollution indicators (WHO/UNEP 2003).

\section{Matherial and methods}

\section{Sampling stations.}

This study was conducted during a 6 month period along two different seasons: spring time (from March to April 2019) and summer time (from May until August 2019). The sea waters samples were collected in 6 different stations distributed along the coastline (respectively: Triport, Soda forest, Vlora port, Marina school, Radhimë, Orikum close to Pashaliman military base) (Figure 1).

Figure 1: Sampling stations along Vlora bay, Albania

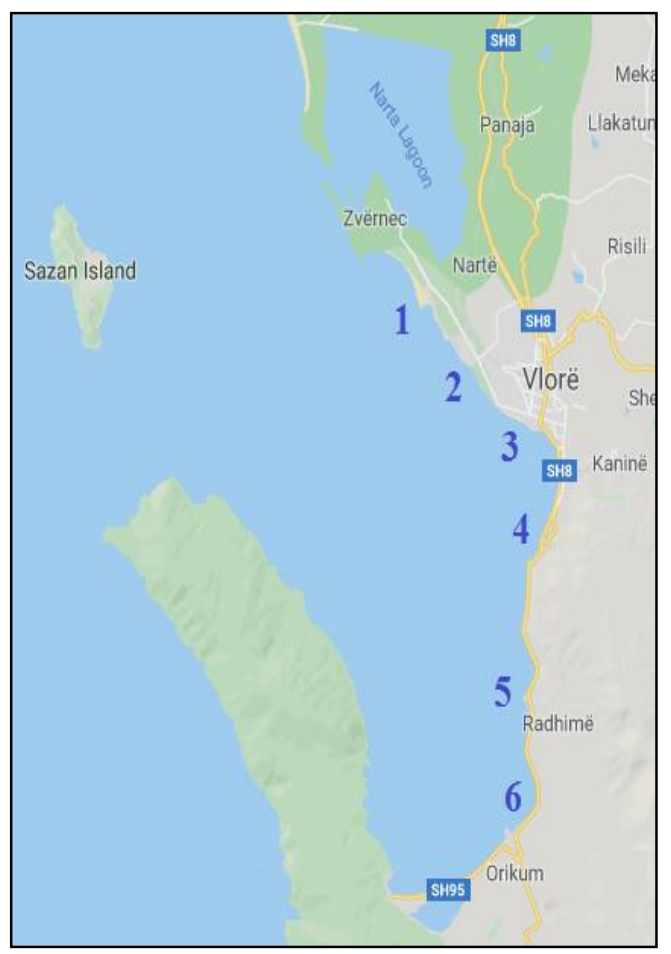

\begin{tabular}{|c|c|c|c|}
\hline Locations & Sta. & Altitude & Longitude \\
\hline Triport & St. 1 & $19^{\circ} 27^{\prime} 13.6^{\prime \prime}$ & $40^{\circ} 28^{\prime} 11.5^{\prime \prime}$ \\
\hline $\begin{array}{c}\text { Soda } \\
\text { forest }\end{array}$ & St. 2 & $19^{\circ} 28^{\prime} 19.5^{\prime \prime}$ & $40^{\circ} 27^{\prime} 14.5^{\prime \prime}$ \\
\hline $\begin{array}{c}\text { Vlora } \\
\text { Port }\end{array}$ & St. 3 & $19^{\circ} 29^{\prime} 10.9^{\prime \prime}$ & $40^{\circ} 27^{\prime} 03.2$ \\
\hline $\begin{array}{c}\text { Marina } \\
\text { school }\end{array}$ & St. 4 & $19^{\circ} 29^{\prime} 37.9^{\prime \prime}$ & $40^{\circ} 26^{\prime} 12.8^{\prime \prime}$ \\
\hline Radhimë & St. 5 & $19^{\circ} 28^{\prime} 46.6^{\prime \prime}$ & $40^{\circ} 21^{\prime} 43.8^{\prime \prime}$ \\
\hline Orikum & St. 6 & $19^{\circ} 28^{\prime} 46.6^{\prime \prime}$ & $40^{\circ} 20^{\prime} 35.0^{\prime \prime}$ \\
\hline
\end{tabular}

Sampling techniques for microbiological analyses.

To perform bacteriological analyses the procedures from water sampling to conservation and treatment were, according to the monitoring water quality standards. (WHO 1995). The amount of analyst water was 0,5L. During the sampling was recorded the date and exact time, water temperature and same data on the weather condition. 


\section{2-24 November, $2019 \quad$ Paris, France}

Samples were taken in $15-30 \mathrm{~cm}$ depth at a distance $50 \mathrm{~cm}$ from the coast line. After collecting, samples were transported in thermobox to the lab within 24 hours, according the regulations and standards (Borrel Fontelles \&Winkler, 2006).

\section{Microbiological analysis}

The microbiological analyses were conducted in Microbiological Lab of Biology Department, University Ismail Qemali of Vlora. These analyses were referred to International Standards Techniques (ISO 1991; CEC 1978; WHO 1984; ISO 1999; UNECE 1994; Camper et al. 1996). Determination of total and fecal coliform was performed according to MNP methods with EC media. Diluted samples were cultured in $44^{\circ} \mathrm{C}$ for $24-48$ hours, for confirmatory tests. The data were expressed statistically by the number of organisms in $100 \mathrm{ml}(\mathrm{MPN} / \mathrm{ml})$.

\section{Results and discussion}

The aim of our study was the evaluation of water quality in microbiological point of view and also the impact of seasonal changes in the dynamics of fecal coliform bacteria. For a completed pattern we analyzed 6 different sampling stations of Vlora bay.

\section{Microbiological analysis}

Recently it has been noticed that a large variety of antropogenical sources affecting Vlora coastline, such as: sewage discharge, human waste, non-treated wastewaters, are being increased. This leads to increasing levels of coliform bacteria and also human interest pathogens in sea waters.

Table 1: Table of descriptive statistic of all sampling stations (MPN/ 100ml)

\begin{tabular}{|l|l|l|l|l|l|l|}
\hline Statistics & St. 1 & \multicolumn{1}{|c|}{ St. 2 } & St.3 & St. 4 & St. 5 & St. 6 \\
\hline Mean & 811.22 & 1971.67 & 3717.78 & 2302.11 & 173.72 & 251.89 \\
\hline $\begin{array}{l}\text { Std. Error } \\
\text { of Mean }\end{array}$ & 241.091 & 512.260 & 391.888 & 472.017 & 34.435 & 41.082 \\
\hline Median & 295.00 & 380.00 & 4800.00 & 2400.00 & 120.00 & 380.00 \\
\hline Mode & 2400 & 4800 & 4800 & 4800 & 36 & 380 \\
\hline $\begin{array}{l}\text { Std. } \\
\text { Deviation }\end{array}$ & 1022.864 & 2173.334 & 1662.640 & 2002.600 & 146.097 & 174.297 \\
\hline \begin{tabular}{l} 
Variance \\
\hline
\end{tabular} & 1046251.359 & 4723381.412 & 2764371.242 & 4010405.399 & 21344.448 & 30379.516 \\
\hline
\end{tabular}




\section{2-24 November, $2019 \quad$ Paris, France}

\begin{tabular}{|c|l|l|l|l|l|l|}
\hline Skewness & 1.022 & .506 & -1.126 & .254 & .513 & -.337 \\
\hline $\begin{array}{l}\text { Std. Error } \\
\text { of Skewness }\end{array}$ & .536 & .536 & .536 & .536 & .536 & .536 \\
\hline Kurtosis & -.983 & -1.779 & -.330 & -1.718 & -1.435 & -1.916 \\
\hline $\begin{array}{l}\text { Std. Error } \\
\text { of Kurtosis }\end{array}$ & 1.038 & 1.038 & 1.038 & 1.038 & 1.038 & 1.038 \\
\hline Minimum & 36 & 13 & 380 & 44 & 13 & 36 \\
\hline Maximum & 2400 & 4800 & 4800 & 4800 & 380 & 440 \\
\hline
\end{tabular}

The area of study is being used for recreative activities such as, swimming, recreative fishing and sailing. Fecal pollution of bathing area might present risque for public health, because feces might contain bacteria, viruses and protozoa, which might be swallowed and led to the evolution of several illnesses. (Am 2003).

In table. 1 is presented a statistical description of the reported data in all the studied stations. It is noticed that the skewness values are $(<|2|)$ and the kurtosis coefficient is positive for all the sampling stations. Values are stabile and with a low variance, which indicate a low environmental impact in all sampling stations.

Based on our data, two of the stations, St3 (Vlora Port) and St 4 (Marina school) represents the higher values of coliform bacteria. This high pollution level is expected, due to the presence of Vlora Port, as an important anthropogenic source. During the inspection of S4 study area (located close Marina Bay), were evidenced several canals with active urban waste waters.

A clear representation of the obtained data shows that the total numbers of coliform bacteria is highest in sampling station 3 (Vlora port) and 4 (Marina school) with a maximum value of $4800(\mathrm{MPN} / 100 \mathrm{ml})$. The lower mean value of these sampling stations is 44 (MPN/100ml). Based on the standard of water qualities (U.S. EPA 1986) more than 200 (MPN/100ml) we can state that at both these beaches is not safe to swim. 


\section{2-24 November, $2019 \quad$ Paris, France}

Figure 2: Fecal coliform bacteria value March - August 2019 (MPN/ 100ml)

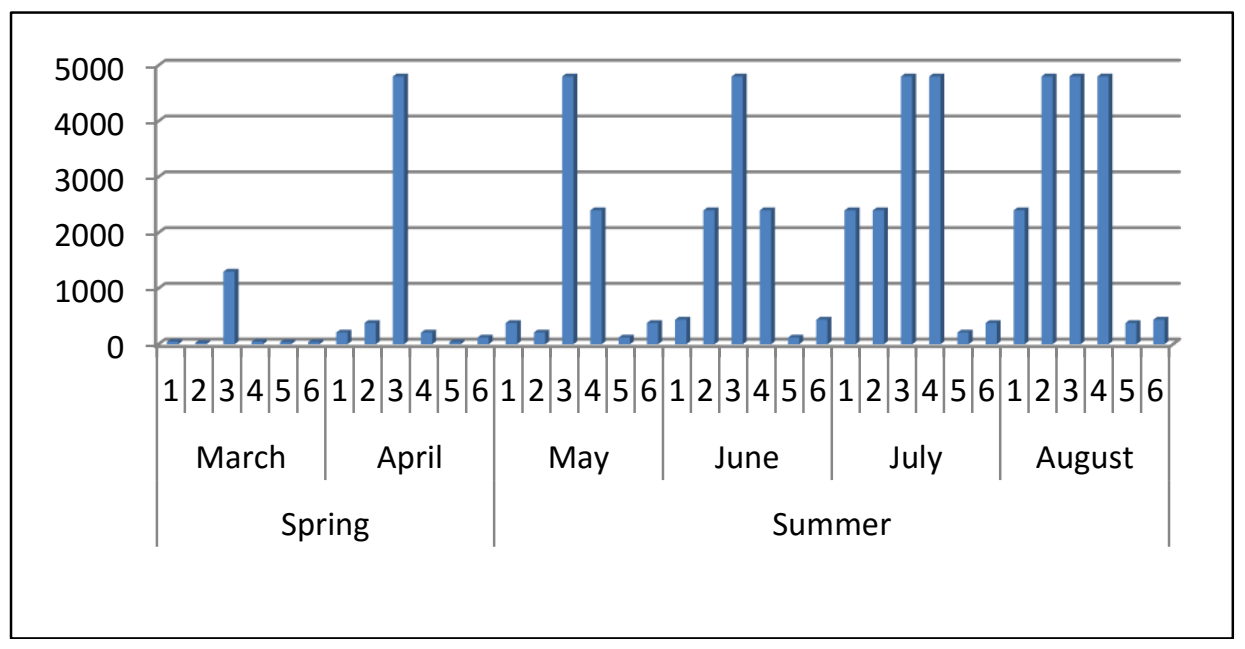

Vlora port is located along the coast line and includes a large variety of commercial activities such as: passengers transport, animal transportation and also transportation of industrial materials (IMO 2013; NPS 2010). Regardless their shape and dimensions, environmental impact on sea depends on these commercial activities (Gomez et al., 2015). They are such complicated systems with a wide range of environmental IP acts including the release of water, air and soil (Darbrato et al., 2005).

In the portal area and surroundings different activities such as fishing, a nondeveloped infrastructure, deposition and conservation of several hazardous materials with ought to respect the appropriate regulations, violating the protocols and standards regarding environmental security, might lead to an escalated environmental impact.

The process of water absorbing and meeting from the ships, when they are anchored had affected the distribution of pollution as well and pathogen bacteria which as a consequence would have an impact on human health and also on environmental state $(\mathrm{Ng}$ et al., 2015).

The process of water absorbing and meeting from the ships, when they are anchored had affected the distribution of pollution as well and pathogens bacteria which as consequence would have impact on human health and also on environmental state ( $\mathrm{Ng}$ et al., 2015). Also the continuous ship movements in a limited area and accidental cases are contributors on increasing the amount of several hazardous materials realized in this area (Trozzi\&Vaccaro 2000).

During the summer time has noticed an increase of values almost in all sampling stations. This is due to the increase of the number of people frequenting the area and the high temperatures, typically of the season. A pattern indicated by the seasonal variations of temperature and also and also by runoff conditions. 


\section{2-24 November, $2019 \quad$ Paris, France}

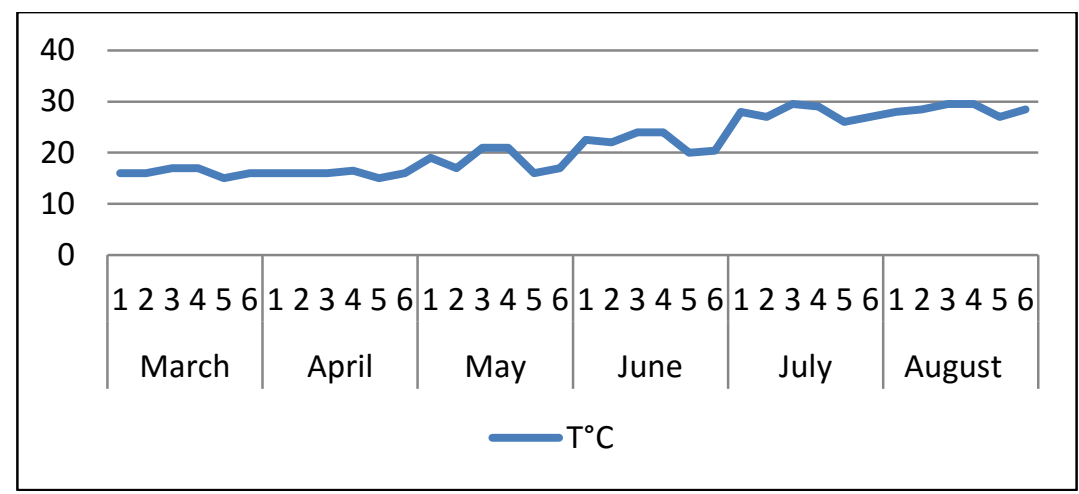

The high values of coliform bacteria on May might be associated with high temperature and runoffs. From June to August, there have been high values of temperature according to summer time this associated with elevated values of coliform bacteria.

Table 2: Table of correlation of coliform bacteria with temperature

\begin{tabular}{|l|c|c|c|}
\hline \multicolumn{2}{|c|}{ Correlations } & Coliform Bacteria & Temperature \\
\hline \multirow{3}{*}{$\begin{array}{l}\text { Coliform } \\
\text { Bacteria }\end{array}$} & Pearson Correlation & 1 & $.630^{* *}$ \\
\cline { 2 - 4 } & Sig. (2-tailed) & & .000 \\
\cline { 2 - 4 } & $\mathrm{N}$ & 108 & 108 \\
\hline \multirow{3}{*}{ Temperature } & Pearson Correlation & $.630^{* *}$ & 1 \\
\cline { 2 - 4 } & Sig. (2-tailed) & .000 & \\
\cline { 2 - 4 } & $\mathrm{N}$ & 108 & 108 \\
\hline \multirow{2}{*}{$* *$ Correlation is significant at the 0.01 level (2-tailed). } \\
\hline
\end{tabular}

Pearson correlation coefficient ( $r$ ) showed a significant correlation between temperature and indicator organisms (total Coliforms and fecal Coliforms). Two asterisks (*) mean p 0.01. Differently to our results Similarly, Guyal et al. found that the indicator organisms (total Coliforms, fecal Coliforms, and salmonellae) were no statistically significant relationships with temperature, $\mathrm{pH}$, turbidity, and suspended solids contents of seawater (Goyal et al., 1977) In another study, Shibata et al. reported that there were no statistically significant relationships between the concentrations levels of enterococci, Escherichia coli, fecal coliform, and C. perfringens and physical-chemical parameters (rainfall, temperature, $\mathrm{pH}$, and salinity) (Shibata et al., 2004).

Also other studies, Blaustein et al. (Blaustein et al., 2013) and Sampson et al. (Sampson et al., 2006) found that temperature was a major factor in the survival of E. coli in surface waters. Place et al. reported that the survival of Salmonella typhimurium and 


\section{2-24 November, $2019 \quad$ Paris, France}

indicator bacteria (coliform and fecal coliform bacteria and fecal streptococci) was considerably affected by temperature (Placha et al., 2001).

Table 3 presents descriptive statistic of coliform bacteria, temperature and $\mathrm{pH}$. It is noticed that the skewness values are $(<|2|)$ and the kurtosis coefficient is positive for all the for all the sampling stations. Values are stabile and with a low variance.

Table 3: Table of descriptive statistic of coliform bacteria (MPN/ 100ml), temperature and pH

\begin{tabular}{|l|l|l|l|}
\hline Statistics & Coliform Bacteria & Temperature & $\mathrm{pH}$ \\
\hline Mean & 1538.06 & 21.10 & 8.13 \\
\hline Std. Error of Mean & 182.844 & .459 & .034 \\
\hline Median & 380.00 & 20.00 & 8.10 \\
\hline Mode & 4800 & 17 & 8 \\
\hline Std. Deviation & 1900.169 & 4.768 & .354 \\
\hline Variance & 3610640.771 & 22.732 & .125 \\
\hline Skewness & .941 & .475 & .403 \\
\hline $\begin{array}{l}\text { Std. Error } \\
\text { Skewness }\end{array}$ & .233 & .233 & .233 \\
\hline $\begin{array}{l}\text { Kurtosis } \\
\text { Std. Error of Kurtosis }\end{array}$ & .461 & -1.209 & -.764 \\
\hline $\begin{array}{l}\text { Minimum } \\
\text { Maximum }\end{array}$ & 13 & .461 & .461 \\
\hline
\end{tabular}

$\mathrm{pH}$ has a direct impact on the recreational users of water only at very low or very high values. Under these circumstances, $\mathrm{pH}$ may have effects on the skin and eyes (WHO 2003). According to Hernendez-Delgado and toranzos (1995) the optimum $\mathrm{pH}$ for coliform growth is $\mathrm{pH}$ 6-7, while for coliphages the optimum is $\mathrm{pH}$ 7.0-7.7.

Figure 4 shows high values of $\mathrm{pH}$ in stations: S1 (Triport), S4 (Soba forest), S5 (Radhime) and S6 (Orikum) which had a low cargo of coliform bacteria, so these situations present good quality of sea water. The stations with high values of coliform bacteria: S 3 (Vlora port) and S4 (Marina school) appear with low pH values, so these 


\section{2-24 November, $2019 \quad$ Paris, France}

stations do not present good quality of sea water. Based an the above, we can say that $\mathrm{pH}$ affects coliform bacteria growth.

Figure 4: $p H$ values in all sampling stations

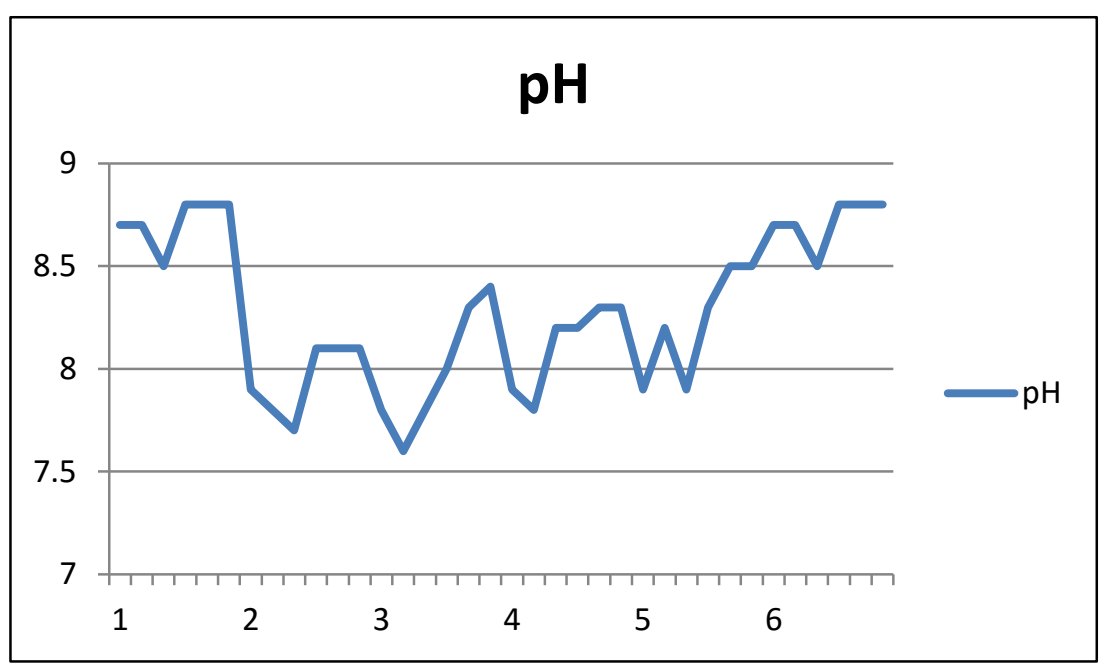

The salinity in seawater samples was in the range between 27.7 and $38.2 \mathrm{mg} / \mathrm{L}$. Pearson correlation analysis showed that there was a significant inverse correlation between the concentrations levels indicator microorganisms (total Coliforms and fecal Coliforms) salinity of seawater samples. Therefore, decreasing of salinity indicated a corresponding increase in the values of coliform bacteria.

A negative effect of salinity is attributed to specific characteristics of sea water, such as osmotic pressure and the toxicity of inorganic salts (Gauthier et al., 1987). Most studies, for example, Rozen and Bikini found a reverse correlation between the level of E. coil and water salinity in seawater (Rozen\&Belkin, 2001). An inverse correlation between survival of E. coli and salinity of water has also been demonstrated by Anderson et al. (Anderson et al., 2005). In contrast to our studies, Jozić et al showed that there was no statistically significant effect of salinity on the E. coli bacteria (Solic\&Krstulovic, 1992).

\section{Conclusions}

From hygiene-center monitoring of sampling stations located along Vlora coastline, it is noticed that the problem of nontreatement of waste- discharges is not resolved yet. Due to the large numbers of waste canals the most problematic area is around the Marina school bay. Flora bay beaches are highly of the basic nature and does not represent any risk to human health. With the aim to protect human health is important a continuous monitoring process of the coastline. 


\author{
Paris, France
}

\title{
Reference
}

1. Alm EW, Burke J, Spain A. Fecal indicator bacteria are abundant in wet sand at freshwater beaches. Water Res. 2003;37(16):3978-82.

2. STRICKLAND, J.D.H. \& PARSONS, T.R., (1972): A practical handbook of seawater analysis. 2nd ed. -Bull. Fish. Res. Bd. Canada.

3. Kamizoulis G, Saliba L. Development of coastal recreational water quality standards in the Mediterranean. Environ (2004). Int 30: 841-854.

4. Kennish, M. J. Estuarine and Marine Pollution. CRC Press, Boca Raton, FL, 1997, 524pp.

5. Wilkes G, Edge T, Gannon V, Jokinen C, Lyautey E et al. Seasonal relationships among indicator bacteria, pathogenic bacteria, Cryptosporidium oocysts, Giardia oocysts, and hydrological indices for surface waters within and agricultural landscape. Water Res (2009). 43: 2209-2223.

6. Camper A.K. Jones, W.L., Hayes, J.T., (1996). Effect of growth conditions on the presence of coliforms in mixed-population biofilms, Applied and Environmental Microbiology, 62: 4103-4018.

7. ISO (International Organization for Standardization). (1991). ISO 56672:1991(E). Water Quality—Sampling, Part 2: Guidance on Sampling Techniques. Second edition 1991-07-01.

8. CEC (Commission of European Communities). (1978). Council Directive of 18 July 1978 on the quality of fresh waters needing protection or improvement in order to support fish life., (78/659/EEC). Official Journal, L/222: 1-10.

9. APHA 1992 Standard Methods for the Examination of Water and Wastewater. 18th edition, American Public Health Association (APHA), American Water Works Association (AWWA) and Water Pollution Control Federation (WPCF), Washington, D.C.

10. Geldreich, E.E. 1967 Fecal coliform concepts in stream pollution. Water and Sewage Works, 114, 98-110.

11. WHO 1993 Guidelines for Drinking Water Quality. 2nd Edition, World Health Organization, Geneva.

12. Fleisher JM, Kay D, Wyer MD, Godfree AF. Estimates of the severity of illnesses associated with bathing in marine recreational waters contaminated with domestic sewage. Int J Epidemiol (1998) 27: 722-726.

13. Kay D, Fleisher JM, Godfree AF, Jones F, Salmon RL et al. Predicting the likelihood of gastero-enteritis from sea bathing: results from randomized exposure. Lancet (1994).344: 905-909.

14. SALYERS A.A, WHITT D.D. Microbes and a human in imbalance: infectious diseases. In: Microbiology. Diversity, pathogenicity and environment. PWN, Warsaw, 2012 [In Polish].

15. The Microbiology of Recreational and Environmental Waters (2000), UK govermant. 


\section{2-24 November, $2019 \quad$ Paris, France}

16. WHO/UNEP: Consulting Meeting on Criteria and Standards for Health-related Monitoring of Coastal Recreational Waters. 2003.

17. WHO (1995) Manual for Recreational water and Beach Quality Monitoring and Assessment. Draft. WHO, regional Office for Europe, European Centre for Environment and Health.

18. Borrell Fontelles \& Winkler, 2006. DIRECTIVE 2006/7EC of European Parliament andd the Council of 15 February 2006: Concerning the Management of Bathing Water Quality and Repealing Directive 76/160/EEC. -Official Journal of European Union, nr 64:35-51.

19. WHO (1995) Manual for Recreational water and Beach Quality Monitoring and Assessment. Draft. WHO, regional Office for Europe, European Centre for Environment and Health.

20. World Health Organization (1984). Microbiological Methods for water quality monitoring. Second report, Copenhagen, 4

21. UNECE 1994 Standard Statistical Classification of Surface Freshwater Quality for the Maintenance of Aquatic Life. In: Readings in International Environment Statistics, United Nations Economic Commission for Europe, United Nations, New York and Geneva.

22. U.S. Environmental Protection Agency (EPA)(1986) Bacteriological ambient water quality criteria; availability Federal Register, 51, 8012.

23. IMO. Oceans and the Law of the Sea. International Maritime Organization(US): Office of the Legal Affairs of the United Nations.New York, 2013.

24. National Ports Strategy. Infrastructure for an economically, socially, and environmentally sustainable future. National Transport Commission: Infrastructure Australia, Sydney, Australia. 2010 Dec; 1-30. Available from: infrastructureaustralia.gov.au/policypublications/publications/file/National_Ports_Strategy_DEC2010_v2.pdf.

25. Gomez AG, Ondiviela B, Puente A, Juanes JA. Environmental risk assessment of water quality in harbor areas: a new methodology applied to European ports. Journal of Environmental Management. 2015; 155: 77-88. pmid:25819350

26. Darbrato RM, Ronza A, Stojanovic TA, Wooldridge C, Casal J. A procedure for identifying significant environmental aspects in sea ports. Marine Pollution Bulletin, 2005; 50(8): p. 866-74. pmid:15946703

27. Ng C, Le TH, Goh SG, Liang L, Kim Y, Rose JB et al. A Comparison of Microbial Water Quality and Diversity for Ballast and Tropical Harbor Waters. PLoS One, 2015; 10(11): e0143123. pmid:26575481

28. Trozzi C, Vaccaro R, Environmental impact of port activities. In: Brebbia CA, Olivella J, editors. Maritime Engineering and Ports II, Rome, Italy; 2000: 151161. Available

Fom: https://www.witpress.com/Secure/elibrary/papers/PORTS00/PORTS00013FU.pdf

29. Goyal SM, Gerba CP, Melnick JL. Occurrence and distribution of bacterial indicators and pathogens in canal communities along the Texas coast. Appl Environ Microbiol. 1977;34(2):139-49. 


\section{2-24 November, $2019 \quad$ Paris, France}

30. Shibata T, Solo-Gabriele HM, Fleming LE, Elmir S. Monitoring marine recreational water quality using multiple microbial indicators in an urban tropical environment. Water Res. 2004;38(13):3119-31.

31. Blaustein RA, Pachepsky Y, Hill RL, Shelton DR, Whelan G. Escherichia coli survival in waters: temperature dependence. Water Res. 2013;47(2): 569-78.

32. Sampson RW, Swiatnicki SA, Osinga VL, Supita JL, McDermott CM, Kleinheinz G. Effects of temperature and sand on E. coli survival in a northern lake water microcosm. J Water Health. 2006;4(3):389-93.

33. Placha I, Venglovský J, Sasakova N, Svoboda IF. The effect of summer and winter seasons on the survival of Salmonella typhimurium and indicator microorganisms during the storage of solid fraction of pig slurry. J Appl Microbiol. 2001;91(6):1036-43.

34. Hernandez-Delgado, E.A. \& toranzos, G.A. 1995. In situreplication studies of somatic and male-specific coliphages in a tropical pristine river. Water Sci. Technol. 31: 247-250.

35. WHO (World Health Organization). 2003. Guidelines for Safe Recreational for Water Environments Vol 1: Coastal and Freshwaters. World Health Organization, Geneva

36. ISO 5667-2 (1991) Water quality --Sampling -- Part 2: Guidance on sampling techniques, TC 147/SC6.

37. ISO Norme Internationale. Nos. 5666 (1986). 8288 (1990). 9174 (1999).

38. Gauthier MJ, Munro PM. Mohajer S (1987) Influence of salts and sodium chloride on the recovery of Escherichia coli from seawater. Curr Microbiol. 1987;15(1):5-10.

39. Rozen Y, Belkin S. Survival of enteric bacteria in seawater. FEMS Microbiol Rev. 2001;25(5):513-29.

40. Anderson KL, Whitlock JE, Harwood VJ. Persistence and differential survival of fecal indicator bacteria in subtropical waters and sediments. Appl Environ Microbiol. 2005;71(6):3041-8.

41. Šolić M, Krstulović N. Separate and combined effects of solar radiation, temperature, salinity and $\mathrm{pH}$ on the survival of faecal coliforms in seawater. Mar Pollut Bull. 1992;24(8):411-6. 